\title{
The Impact of R\&D Expenses on Firm Performance: Empirical Witness from the Bist Technology Index
}

\author{
Zied Bouaziz ${ }^{1 *}$ \\ ${ }^{1}$ Accounting assistant in Higher Institute of Management of Gabes-Tunisia member of the research \\ unit "Governance", Gabes, Tunisia \\ "Zied Bouaziz, E-mail: ziedbouazi@yahoo.fr
}

\begin{abstract}
The relationship between investment in $R \& D$ and company performance has attracted the interest of several research. Vast amount of research have been carried to figure out whether this relationship exist or not. Some researchers suggest that there is no relationship between $R \& D$ expenses and firm performance; others put forward the existence of negative or positive relationship. It can be asserted that possible existence as useful information can be consumed by managers to increase the market value of firms. In that respect, the main aim of this research is to reveal the relationship between $R \& D$ and firm performance by taking into account 12 companies that are listed on the BIST Technology Index for 5 years periods (between 2010 and 2014). In order to accomplish this purpose, we employed pooled regression model and cross sectional time series analysis technique. In general, although negative and positive coefficients are found, almost, all of them is not statistically significant. In other words, according to outcomes, it can be claimed that there is no relationship between $R \& D$ and firm performance which is line with previous studies.
\end{abstract}

Keywords

$R \& D$ expenses, firm performance, BIST, technology index

\section{Introduction}

The transition from an industrial economy to a knowledge economy has had consequences for an economic recovery, accounting and market the intangible. Intangible capital is the main factor of differentiation and competitiveness of enterprises (Penman, 2009).

Investment in $R \& D$ are considered in relation to other intangible investments, as an important form of investment in technology (Karl-Heinz, 2005). Companies have invested substantial sums in R\&D over the past two decades to generate future economic benefits for the various stakeholders in the firm.

The growth of technological firms is based on innovative products and services, led them to invest in Research and Development R\&D (Lantza \& Sahutb, 2005). It is significant to note that the relationship between $R \& D$ expenditures and firm's performance is vital for firm's managers whose aim is to maximize the present values of stockholders' value (Tubbs, 2007).

In that context, the relationship between R\&D expenditures and firm performance has been discussed and carefully studied for many years. Vast amount of research have been carried to figure out whether this relationship exist or not. Some researchers advocate that there is no relationship between R\&D expenditures and firm performance; others suggest the existence of negative or positive relationship. It can be claimed that possible existence as an information can be employed by managers to increase the market value of firms. In that respect, the main aim of this research is to reveal the relationship between R\&D expenditures and firm performance of 12 companies that are listed on the BIST Technology 
Index for 5 years periods (between 2010 and 2014). In order to accomplish this purpose, pooled OLS test and cross sectional time series analysis technique were employed.

\section{Literature Review}

Over the past two decades, following the substantial rise in spending on Research and Development (R\&D), we witness the emergence of an abundant literature on this particular type of intangible assets including its evaluation, its accounting, fell back on his company's performance ... Previous research generally confirm the positive contribution of investment in R\&D to the company's performance and its valuation by the market (Griliches, 1981; Cockburn \& Griliches, 1988; Lev \& Sougiannis, 1996; Blundell, Griffith, \& Van Reenen, 1999; Canibano, Garcia-Ayuso, \& Sanchez, 2000; Chan, Lakonishok, \& Sougiannis, 2001; Toivanen, Stonenman, \& Bosworth, 2002; Hall \& Oriani, 2006). Indeed, while expenses decreased $R \& D$ cash flows and current profits, they positively affect the prospects of firms have higher future earnings. Investment in R\&D is especially for firms operating in high-technology sectors, an important strategic element and a significant expense, pledge of their innovative potential to ensure their market competitiveness and ensure their viability.

The relationship between investment in $R \& D$ and company performance has attracted the interest of several research. It is commonly shared by the research that these investments contribute positively to the company's performance (Sougiannis, 1994; Canibano, Garcia-Ayuso, \& Sanchez, 2000). However, to the extent that some leaders may tend to undertake investments in R\&D activities in order not to improve the performance of the company but rather to preserve their place at the company's head.

This investment is beneficial to businesses as it allows them to achieve improved performance and a higher valuation by the market (Lev \& Sougiannis, 1996; Eberhart, Maxwell, \& Siddique, 2004; Chan, Lakonishok, \& Sougiannis, 2001). However, finding a direct relationship between R\&D and future performance of a company could be quite questionable as it could take several years for the R\&D projects generate revenue to the firm which now remains uncertain. Indeed, investment in R\&D creates value, but it is always difficult for an investor to reliably estimate its impact on business results. This difficulty is due to the same characteristics of this investment (risk, time horizon, uncertainty ...). Indeed, the huge costs involved in $R \& D$ activities can generate either high levels of performance in case of innovation success is zero returns on failure.

Despite the uncertainty of future benefits and assessment difficulties associated with investments in R\&D, empirical research studying the link between spending R\&D and company performance have continued to increase. During the last three decades, and even today a large literature attempts to identify the impact of $R \& D$ expenditure on the financial performance of a firm.

Many empirical researches have been carried to provide evidence that shows the correlation between R\&D expenditures and firm performance. Many researchers have been interested in the correlation between R\&D expenditures and the firm performance that is the indicator of firms' market value, and positive and significant relationship has been shown. Some of them are Liang and Zhang (2005) figured out the relationship with 72 hi-tech companies as the sample. Connolly and Hirschey (1984) focused on 390 firms Fortune 500, and found the existence of a positive and significant relationship between the R\&D expenditures and the firm's value. Similarly, Hongwei and Cheng (2006) analyzed the sample to 96 companies and figured out the positive impact of R\&D investments on firms' market value.

In the American context, Ben-Zion (1984) and Pakes (1985) confirm the existence of a significant positive relationship between $\mathrm{R} \& \mathrm{D}$ and the market value of a firm. This result was also confirmed by 
studies carried out in the context of the United Kingdom (UK) (Blundell, Griffith, \& Van Reenen, 1999; Toivanen, Stonenman, \& Bosworth, 2002). Similarly, the study of Bae and Kim (2003) conducted in three contexts, American, German and Japanese shows that the effect of investments in R\&D on the market value of a firm is positive and significant for all countries and is stronger in the case of Japanese companies. Pazderka and Johnson (1993), using Canadian business panel data for different periods (52 firms for the period 1985-1987, 54 companies for the period 1986-1988, 47 companies for the period 1985 to 1988), says the presence of a strong positive relationship between R\&D and the market value of a firm.

Zhong and Zhou (2012) do the same work with a stochastic frontier model, and obtained the same conclusion with data of China market. According to market performance indicator perspective, Tobin's Q, Hall, Thoma and Torrisi (2007) found positive and significant association as well. Also and Koellinger (2008), evaluated e-commerce companies in Europe. In his research, he found that companies engaged in internet-based innovations illustrate greater performance than firms which do not invest in R\&D. Vaccaro, Parente and Veloso (2010) determined the effective use of information management tools to develop new products and services, positive effect on companies' performance.

In this context, several studies found a positive correlation between R\&D spending and Tobin's Q (Hirschey \& Weygandt, 1985; Chung \& Jo, 1996; Agrawal \& Knoeber, 1996; Bosworth \& Rogers, 1998; Chen \& Yang, 2003). Similarly the study of Cockburn and Griliches (1988), based on a sample of 722 US companies, showed the existence of a positive correlation between Tobin's Q and R\&D. However, this relationship is still strongly influenced by sectoral effects.

Yew, Mira and Chee (2006) on US companies show that investment in R\&D has a positive and significant impact on the growth opportunities of a firm as they are measured by the ratio of market value over book value of assets.

Canibano, Garcia-Ayuso and Sanchez, (2000) also showed a significant positive relationship between yields on securities and R\&D. Bloch (2003), on a sample of Danish companies; found that intensive enterprises in R\&D emit higher dividend yields than those with no R\&D activities. Recently, Chan, Faff, Gharghori and Ho (2007) confirmed the existence of a positive relationship between R\&D and market returns and whatever the method of accounting of these expenditures.

However, if the majority of studies agree on the positive contribution of R\&D expenditure to the market value of the company some others fail to confirm such a contribution. The study Chan, Lakonishok and Sougiannis (2001) shows that stock returns made by companies engaged in R\&D activities do not differ significantly from those made by companies that are not engaged. Hung, Lee and Lin (2006), on a sample of 258 US firms over the period from 1985 to 1999, found that the relationship between R\&D intensity and Tobin's $Q$ at the level of firms operating in high-tech sectors is not significant. This non significant effect of $R \& D$ performance suggests that firms operating in high-tech sectors cannot increase their competitive advantage by doing only increased their R\&D. Merino, Srinivasan and Srivastava (2006), on a sample of 254 US companies found that while R\&D expenses have no significant effect on shareholder value measured by Tobin's Q, they however decrease variability.

The study of Casta, Escaffre and Ramond (2007) carried on businesses owned by European financial markets, shows that France, Britain and Germany, costs R\&D generally have a negative impact on the operating result. 


\section{Method}

\subsection{Data}

Turkey is strategically located in the center of the Europe, the Middle East and Africa region, which provides many advantages. Turkey offers investment and business opportunities to foreign investors in various sectors including ICT. While Foreign Direct Investment continues to flow into the ICT sector, the total Foreign Direct Investment inflow into Turkey exceeded 10 billion USD in 2011 and 2012 after the economic crisis of 2008. On average, $2.5 \%$ of the Foreign Direct Investment inflow during those years was to the ICT sector.

Stable economic growth and recent data on the correlation between increasing GDP and ICT spending in Turkey shows that the ICT sector has a promising future. Between 2012 and 2017 the Turkish IT market is projected to grow at a rate of $7.4 \%$, while the regions of the Middle East and Africa combined are expected to grow by $9.6 \%$.

The book and market information of the 12 companies that are listed on the BIST technology Index for 5 years periods (between 2010 and 2014) is used for analysis. In order to obtain the data set (http://www.imkb.gov.tr) and (http://www.kap.gov.tr), and websites of firms were examined in detail.

\subsection{Dependent, Independent and Control Variables}

Table 1 demonstrates the dependent, independent and control variables taken into account for our research. Notably, dependent variables shown below were selected as performance indicators.

Table 1. Dependent, Independent and Control Variables

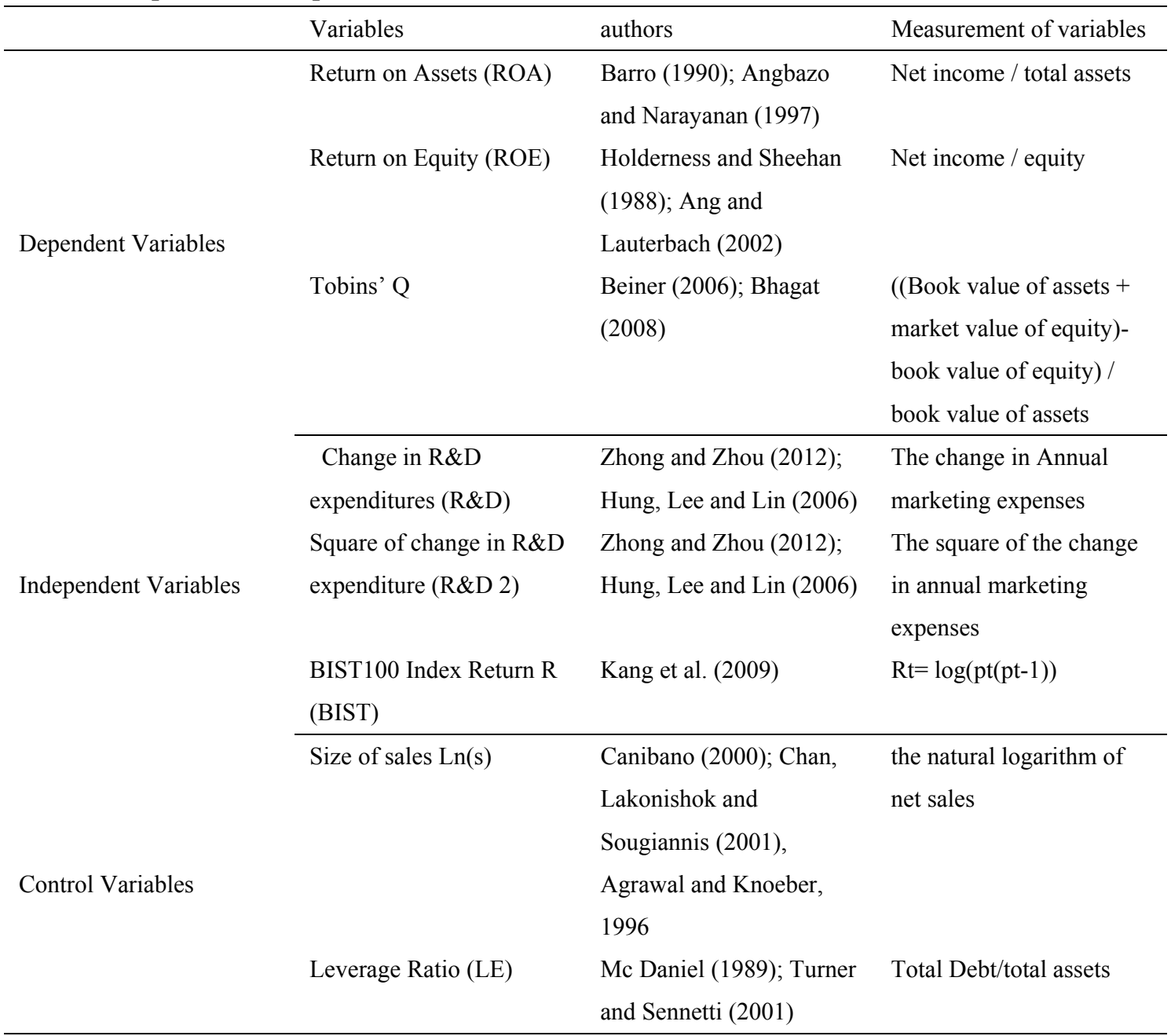




\section{1) Return on Assets (ROA)}

This is the "return on assets" or "economic return". It is calculated as the ratio between net operating income and total assets. This ratio expresses the general profitability of the company highlights the relationship between the results generated by the company and the assets that generate the license.

2) Return on Equity (ROE)

This is the "return on equity" or "equity rate of return". This is the ratio between net income and shareholders' equity. This ratio is often considered one of the most important financial ratios. It measures the ability of a company to generate profits from its net equity. This ratio of particular interest to shareholders whose focus is on profit that pays their contributions. It helps to know how much net income the company is able to achieve for every euro invested or reinvested in the company by shareholders.

3) Tobins'Q

Tobin's $\mathrm{Q}$ is a measure of the total anticipated rents, on a finite horizon. It is calculated by dividing the market value of the firm, the market value of equity (market value) plus the debt market value to the replacement cost of its assets.

A Tobin Q greater than 1, that is to say, the market value of the firm exceeds the replacement cost of its assets, means that the profitability generated by all assets of the company, and anticipated by the market is higher than the weighted average cost of capital.

\subsection{Model}

Pooled OLS Test and cross sectional time series analysis technique were employed in order to figure out the relationship between $\mathrm{R} \& \mathrm{D}$ expenses and firm performance. In this context, the regression models used for our investigation can be seen below:

$$
\begin{gathered}
\text { ROAit }=\alpha i t+\beta 1 \mathrm{Rdit}+\beta 2 \mathrm{RD} 2 \mathrm{it}+\beta 3 \mathrm{R}(\mathrm{BIST}) \mathrm{it}+\beta 4 \mathrm{Ln}(\mathrm{s}) \mathrm{it}+\beta 5 \mathrm{Leit}+\varepsilon \mathrm{it} \\
\text { ROEit }=\alpha \text { it }+\beta 1 \mathrm{RDit}+\beta 2 \mathrm{RD} 2 \mathrm{it}+\beta 3 \mathrm{R}(\mathrm{BIST}) \mathrm{it}+\beta 4 \mathrm{Ln}(\mathrm{s}) \mathrm{it}+\beta 5 \mathrm{LEit}+\varepsilon \mathrm{i} \\
\text { Tobins'Qit }=\alpha i t+\beta 1 \mathrm{RDit}+\beta 2 \mathrm{RD} 2 \mathrm{it}+\beta 3 \mathrm{R}(\mathrm{BIST}) \mathrm{it}+\beta 4 \mathrm{Ln}(\mathrm{s}) \mathrm{it}+\beta 5 \mathrm{LEit}+\varepsilon i t
\end{gathered}
$$

Shown in Equation Tobins'Q, ROA and ROE performance criteria's, and dependent variables; RD, RD2 and R (BIST). Also, Ln (S) and LE demonstrates control variables. In addition, "i” refers business " $\mathrm{t}$ " periods and " $\mathrm{N}$ " represents the total number of enterprises.

\section{Discussion}

First of all, the effect of R\&D expenditures on firm performance is detected by pooled OLS test. Afterwards, regarding Hausman test results, the fixed or random effects models are used. Under the fundamental assumption of OLS Test that is all companies used in research are same, the outcomes of test are shown in Table 2. According to Table 2, regression results in three panels which are regression results generated by taking into account only one dependent variable ROA, ROE and Tobin's Q in Model 1, Model 2 and Model 3 respectively. There are some positive and negative figures were found, even though none of them is statistically significant at any level of confidence selected. Furthermore, as Coşkun et al. (2010) suggested that any increase in marketing and R\&D expenditures can affect company's performance in some positive way, although an expenditure level that above a certain level, this positive effect may change in a direction of opposite way. Parallel with the idea of them, the R\&D expenditures squared analysis represents that even though it has positive and negative impact on ROE and Tobin's Qperformance measurements, these effects been changed in opposite direction. It can be, thus, advocated that there is concave relationship between firm performance and R\&D expenditures. However, it should not be overlooked that this results are not significant. 
Table 2. Pooled Regression Models

\begin{tabular}{lllc}
\hline & Model 1 & Model 2 & Model 3 \\
& ROA & ROE & Tobins'Q \\
\hline Coeff T-stat Sig & Coeff T-stat Sig & Coeff T-stat Sig \\
C & $-0,175-0,7840,439$ & $-0,739-2,1220,041 * *$ & $0,681-2,7550,009 * * *$ \\
RD & $0,0000,0220,988$ & $-0,032-0,5900,557$ & $2,2420,0750,942$ \\
RD2 & $0,0010,1680,868$ & $0,0061,0420,302$ & $-0,043-0,0130,992$ \\
R(BIST) & $-0,014-0,5320,596$ & $0,0130,2980,765$ & $-31,92-1,2230,227$ \\
Ln(s) & $-0,125-1,6060,112$ & $-0,349-2,5690,013 * *$ & $-44,429-0,5300,599$ \\
LE & $0,0121,0700,292$ & $0,0522,3870,021 * *$ & $34,2102,4890,016 * *$ \\
R2 & 0,426 & 0,190 & 0,227 \\
Adj R2 & 0,392 & 0,098 & 0,139 \\
Observa & 60 & 60 & 60 \\
\hline
\end{tabular}

Notes: $* * *$ Significant at $1 \%$;

$* *$ Significant at 5\%;

*Significant at $10 \%$.

According to pooled OLS test, all companies are the same as used in the analysis is fundamentally assumed, it is not possible to accept that this assumption is exist in market conditions. Hence, Hausman Test is used in order to determine fixed or random effects model for analysis of relationship of R\&D expenditure and firm performance which shown in Table 3. According to the Hausman test outcomes, it is found that fixed effect model is more active than random effect model for all model applied. Therefore, fixed effect model is used for evaluation for all models based on the Hausman test outcomes.

Table 3. Correlated Random Effects-Hausman Test

\begin{tabular}{lcll}
\hline & Model-1 & Model-2 & Model-3 \\
& ROA & ROE & Tobins'Q \\
\hline Hausman Test & 0,756 & 0,571 & 2,401 \\
P-Value & 0.978 & 0,969 & 0.790 \\
\hline
\end{tabular}

Notes: $* * *$ Significant at $1 \%$;

$* *$ Significant at $5 \%$;

*Significant at $10 \%$.

Table 4 illustrates fixed effects and random effects model estimation results depending on Hausman Test. As mentioned above, examination of the fixed effects methods, which taken into account for all, demonstrates similar figures which were obtained from running Pooled OLS Test. Therefore, it can be said that there is no proof which shows statistically significant relationship between R\&D expenditures and firm performance in the context of Turkish firms that are listed on the BIST Information Index.

Table 4. Fixed Effects' and Random Effects'

\begin{tabular}{lll}
\hline Model 1 & Model 2 & Model 3 \\
ROA & ROE & Tobins'Q \\
\hline Coeff T-stat Sig & Coeff T-stat Sig & Coeff T-stat Sig \\
\hline
\end{tabular}




\begin{tabular}{llll}
\hline C & $-0,926-1,0280,311$ & $-1,439-1,0390,306$ & $-68,92-0,7930,009$ \\
RD & $0,0030,0920,923$ & $-0,026-0,4950,624$ & $-4,075-0,1220,942$ \\
RD2 & $0,0010,0640,947$ & $0,0060,8740,387$ & $0,4020,0970,942$ \\
R(BIST) & $-0,014-0,5670,576$ & $0,0130,2780,785$ & $-31,92-1,2230,267$ \\
Ln(s) & $-0,231-0,8360,112$ & $-0,639-1,4910,145$ & $-84,129-0,5300,440$ \\
LE & $0,0581,1090,272$ & $0,0971,3070,234$ & $42,2100,8400,406$ \\
R2 & 0,629 & 0,375 & 0,327 \\
Adj R2 & 0,514 & 0,100 & 0,059 \\
Observa & 60 & 60 & 60 \\
\hline
\end{tabular}

Notes: ***Significant at $1 \%$;

**Significant at 5\%;

*Significant at $10 \%$.

Figure 1 already presented in the article by Konak and Kendirli (2014) indicates the R\&D Expenditures, GDP and Scientists and Engineers per Million People indicators for selected countries throughout the world. The far right refers a country which devotes largest share of GDP for R\&D expenditure. Also, the top of the chart represents a country that has relatively the highest number of scientists and engineers in its population. Eventually, the size of circle reflects the relative amount of annual R\&D spending by indicated country. Having done the interpretation of the chart above, it can be seen that Turkey is on the left bottom side of the chart that means it has information ally lagged behind many countries. This station can negatively affect the main idea of our research which advocates the positive significant correlation. As shown in the analysis part of the research, the correlation between $R \& D$ expenditures and firms performance has not been revealed. The reason of this circumstance can be altered by employing different market data. In other words, whole direction of the country towards the R\&D investments has a vital role that influxes all sectors in country' economic system.

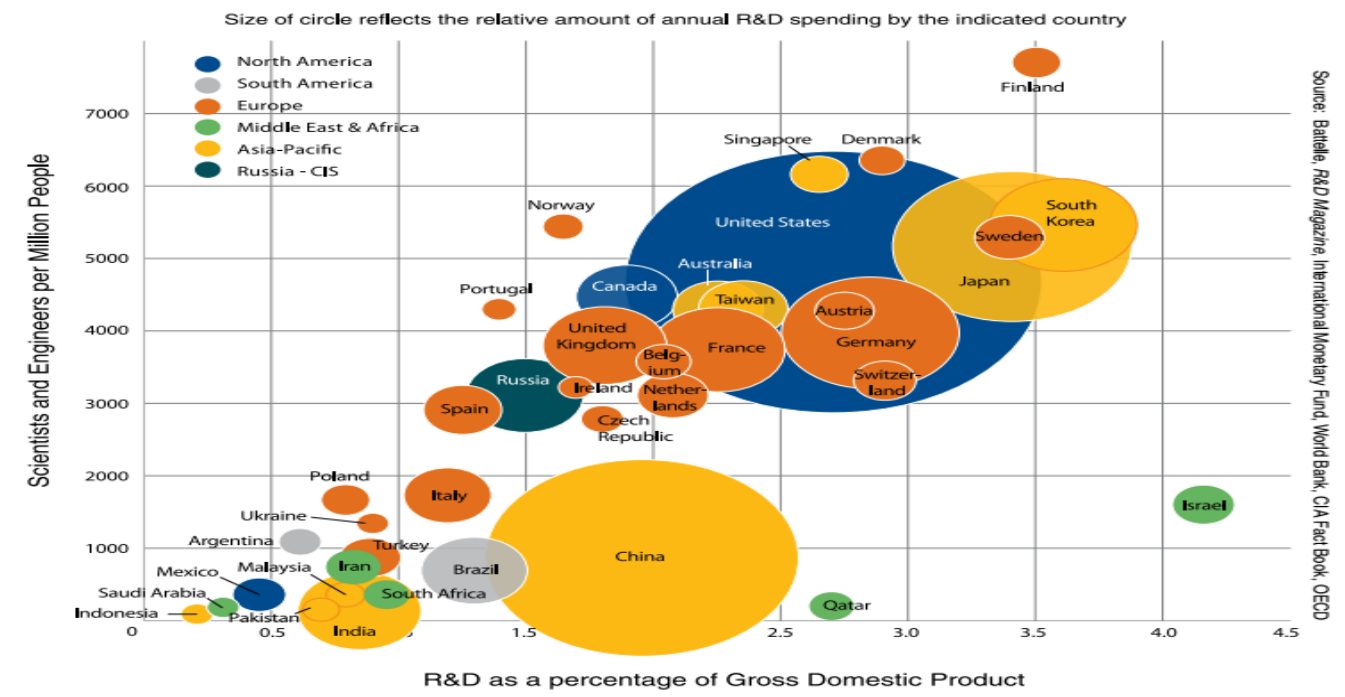

Figure 1. R\&D Expenditures, GDP and Scientists and Engineers per Million People 


\section{Conclusion}

The majority of previous researches show that investment in R\&D plays a major role in the growth and maintenance of the competitive position of firms. However, taking into consideration the managerial opportunism and conflicts of interest between shareholders and managers, investment in R\&D, by its characteristics, can in the absence of effective control over the leaders, strengthen managerial discretion. This opportunistic behavior is especially favored by the specificity of R\&D activities as well as the existence of gaps in accounting rules for $\mathrm{R} \& \mathrm{D}$ costs. According to the theory of roots, leaders are encouraged to over-invest in assets which are highly specific and complementary skills to make costly replacement by competing leaders.

This research investigated the relationship between the relationship between R\&D expenditures and firm performance of 12 companies that are listed on the BIST technology Index for 5 years periods from 2010 to 2014. In order to this aim, pooled OLS test and cross sectional time series analysis technique and pooled OLS method were employed. According to pooled OLS results for Model 1, Model 2 and Model 3, there are some positive and negative figures were figured out, although none of them is statistically significant at any level of confidence selected for both RD and RD2. Notably, It can be, advocated that there is concave relationship between firm performance and R\&D expenditures. Yet, this results are not significant. Analysis of relationship by using cross sectional time series indicates that examination of the Fixed effects methods, which taken into account for all model employed, demonstrates similar figures which were obtained from running Pooled OLS Test. Hence, it can be said that significant relationship between R\&D expenditures and firm performance is not proved for firms that are listed on the BIST Information Index. Moreover, we realized that the Turkey's place in the rankings of the R\&D Expenditures, GDP and Scientists and Engineers per Million People indicators is behind many countries which might be the reason why R\&D expenditure level is not a variable that affect company's market value or performance.

Taking all into the consideration, it can be claimed that in line with the literature the relationship between marketing expenditure and firm performance exists. It should also be, however, highlighted that possible data or market change may reduce or strengthen the reliability of the findings obtained.

To resolve these conflicts, corporate governance theory offers internal and external control mechanisms The role assigned to these mechanisms is to align the behavior of the leaders on the maximization criterion of shareholder wealth.

\section{References}

Agrawel, A., \& Knoeber, C. (1996). Firm performance and mechanisms to control agency problems between managers and shareholders. Journal of Financial and Quantitative Analysis, 31(3), 377-397.

Bae, S. C., \& Kim, D. (2003). The Effect of R\&D Investment on Market Value of Firms: Evidence from the US, Germany and Japan. Multinational Business Review, 11(3), 51-75.

Ben-Zion, U. (1984). The R\&D and investment decision and its relationship to the firm's market value: Some preliminary results. In G. Zvi (Ed.), $R \& D$, patents and productivity, University of Chicago Press (pp. 299-312).

Bloch, C. (2003). The effect of R\&D expenditures on stock market returns for Danish firms. Working paper, 6 .

Blundell, R., Griffith, R., \& Van Reenen, J. (1999). Market share, market value and innovation in a panel of British manufacturing firms. Review of Economic Studies, 66(3), 529-554. 
Bosworth, D., \& Rogers, M. (1998). Research and development, intangible assets and the Performance of large Australian companies. Meulbourne Institute Working Paper, 2(98).

Canibano, L., Garcia-Ayuso, M., \& Sanchez, P. (2000). Accounting for intangibles: A literature review. Journal of Accounting Literature, 19, 102-30.

Casta, J. F., Escaffre, L., \& Ramond, O. (2007). Investissement immatériel et utilité de l'information comptable: Etude empirique sur les marchés financiers européens. Actes du 28 ème Congrès de l'Association Francophone de Comptabilité AFC (cédérom).

Chan, H. W. H., Faff, R. W., Gharghori, P., \& Ho, Y. K. (2007). The relation between R\&D intensity and future market returns: Does expensing versus capitalization matter? Review of Quantitative Finance and Accounting, 29(1), 25-51.

Chan, L., Lakonishok, J., \& Sougiannis, T. (2001). The stock market valuation of research \& development expenditures. Journal of Finance, 56(6), 2431-2456.

Chen, J. R., \& Yang, C. H. (2003). Innovation and market value of newly industrialized countries: The case of Taiwanese electronics firms. Asian Economic Journal, 17(2), 205-220.

Chung, K. H., \& Jo, H. (1996). The impact of security analysts' monitoring and marketing functions on the market value of firms. Journal of Financial and Quantitative Analysis, 31(4), 493-512.

Cockburn, I., \& Griliches, Z. (1988). Industry effects and apropriability measures in the stock market's valuation of R\&D and patents. American Economic Association Papers and Proceedings, 78(2), 419-423.

Connollly, R. A., \& Hirschey, M. (1984). R\&D, Market Struc-ture and Profits: A Value-Based Approach. Review of Economics and Statistics, 66(4), 682-686.

Coşkun, E., Kök, D., \& Yücel, A. (2010). Pazarlama Faaliyetlerinin Firma Değerine Kısa ve Uzun Dönem Etkilerinin İncelenmesi. Finans Politik ve Ekonomik Yorumlar, 47(540), 67-76.

Eberhart, A. C., Maxwell, W. F., \& Siddique, A. R. (2004). An examination of the long-run abnormal returns and operation performance following R\&D increases. Journal of Finance, 59(2), 623-650.

Griliches, Z. (1981). Market value, R\&D and patents. Economics Letters, 7(2), 183-187.

Hall, B. H., \& Oriani, R. (2006). Does the market value R\&D investment by European firms? Evidence from a panel of manufacturing firms in France, Germany and Italy. International Journal of Industrial Organization, 24(5), 971-993.

Hall, B. Hç., Thoma, G., \& Torrisi, S. (2007). The Market Value of Patents and R\&D: Evidence from European Firms. NBER Working Paper. Cambridge.

Hirschey, M., \& Weygandt, J. J. (1985). Amortization policy for advertising and research and development expenditures. Journal of Accounting Research, 23(1), 326-335.

Hongwei, C., \& Changi, Y. (2006). An Empirical Study on the Relationship between R\&D Inputs and Performance. Scientific management research, 110-113.

Hung, S. C., Lee, Y., \& Lin, B. W. (2006). R\&D intensity and commercialization orientation effects on financial performance. Journal of Business Research, 59(6), 679-685.

Karl-Heinz, L. (2005). Managing and reporting intangible assets in research technology organizations. R\&D Management, 35(2), 235-256.

Koellinger, P. (2008). The Relationship between technology, innovation and firm performance-Empirical evidence from e-business in Europe. Research Policy, 37, 1317-1328.

Konak, F., \& Kendirli, S. (2014). Impact of R\&D Expenses on Firm Performance: Empirical Evidence from the BIST Information Technology Index. Procedia of Economics and Business Administration. 
Lantza, J., \& Sahutb, J. (2005). R\&D Investment and the Finan-cial Performance of Technological Firms. International Journal of Business, 10(3), 251-269.

Lev, B., \& Sougiannis, T. (1996). The capitalization, amortization, and value-relevance of R\&D. Journal of Accounting and Economics, 21(1), 107-138.

Liang, L., \& Zhang, H. (2005). An Empirical Study on the R\&D Inputs Performance of High-Tech Enterprises, J. Cent. South University, 232-236.

Merino, M., Srinivasan, R., \& Srivastava, R. K. (2006). Advertising, research and development and variability of cash flow and shareholder value. Working paper, Zips technical report. Zyman Institute of Brand Science.

Pakes, A. (1985). On patents, R\&D and stock market rate of return. Journal of Political Economy, 93(2), 390-409.

Pazderka, B., \& Johnson, L. D. (1993). Firm value and investment in R\&D. Managerial and Decision Economics, 14(1), 15-24.

Penman, S. (2009). Accounting for Intangible Assets: There is Also an Income Statement. A Journal of Accounting, Finance and Business Studies, 45(3), 28-39.

Sougiannis, T. (1994). The accounting based valuation of corporate R\&D. The Accounting Review, 69(1), 44-68.

Toivanen, O., Stonenman, P., \& Bosworth, D. (2002). Innovation and market value of UK firms, 1989-1995. Oxford Bulletin of Economics and Statistics, 64(1), 39-61.

Tubbs, M. (2007). The Relationship between R\&D and Company Performance. Research-Technology Management, 50(6), 23-30.

Vaccaro, A., Parente, R., \& Veloso, F. M. (2010). Knowledge Management Tools, Inter-Organizational Relationships, Innovation and Firm Performance. Technological Forecasting and Social Change, 77, 1076-1089.

Yew, K. H., Mira, T., \& Chee, M. Y. (2006). Size, leverage, concentration and R\&D investment in generating growth opportunities. The Journal of Business, 79(2), 851-876.

Zhong, L., \& Zhou, Q. (2012). R\&D Investment, R\&D Efficiency and Enterprise Performance under the Restriction of Endogenous The Sample of High-tech Segment Industries of China. Soft science, 11-14. 